\title{
Impact of Global Financial Crisis on IDB Member Countries: The Case of Gulf Cooperation Council and Sub-Saharan Africa
}

\author{
ZAFAR IQBAL
}

\section{INTRODUCTION}

The year 2008 witnessed three major crises (food, energy, global financial and economic crises) and their impacts were increasingly felt worldwide. Since the eruption of global financial crisis from September 2008, international financial markets have become more turbulent, and the global economic slowdown is expected to deepen further. Virtually no country, developing or developed, has escaped from the impact of the global financial turbulence, although countries that entered the crisis with less integration into the global economy have generally been less affected. There is an increasing concern that the ongoing global financial turbulence is likely to transform into human crisis, particularly in the developing world.

Although, it will take sometime to assess the full impact of the these crises on developed as well as developing countries, various preliminary estimates have been reported about the losses due to these crises. For example, Kuwait Foreign Minister revealed in Arab Economic Summit that Arab investors lost \$2.5 trillion just in four months (September to December 2008) due to credit crunch. ${ }^{1}$ Similarly, according to the latest estimate by the Asian Development Bank, the global financial market losses reached \$50 trillion in 2008, which is equivalent to one year of world GDP. ${ }^{2}$

Like other developing countries, the impacts of these crises have also been increasingly felt in IDB member countries. Firstly, a large number of member countries were affected due to high food and fuel prices and since September 2008, they are being affected directly and indirectly by the global financial crisis although the channels of transmission are different from those operating in relatively more developed member countries.

Zafar Iqbal <ziqbal@isdb.org> is Senior Economist, Islamic Development Bank, Jeddah, Saudi Arabia. Author's Note: Useful comments of Lamine Doghri, Aftab Cheema, and Mohammad Ahmed Zubair are gratefully acknowledged. Data support by Abdullateef Bello, Aamir Ghani Mir, Abdinasir Nur, and Cheick Amadou Diallo is much appreciated. The views expressed in the paper are the Author's and do not necessarily reflect those of the Islamic Development Bank Group, its Board of Governors, its Board of Directors or its Member Countries.

${ }^{1}$ Arab Economic Summit was held in Kuwait on 19-20 January 2009.

${ }^{2}$ Asian Development Bank (March 2009) "Global Financial Turmoil and Emerging Market Economies: Major Contagion and a Shocking Loss of Wealth". 
The objective of this paper is to provide a preliminary assessment of the first-round and second-round impacts of global financial crisis in two regions of IDB member countries: Gulf Cooperation Council (GCC) ${ }^{3}$ region with relatively more developed member countries and Sub-Saharan Africa (SSA) ${ }^{4}$ region with relatively less developed member countries. The paper is structured as follows. Section II describes main channels of transmissions of global financial crisis in GCC and SSA regions. Section III provides first-order impacts of global financial crisis in both the regions. Section IV provides second-order impacts of global financial crisis on economic outlook of GCC and SSA regions. IDB Group responses to these crises are highlighted in Section V. Conclusion is given in the final Section.

\section{MAIN CHANNELS OF TRANSMISSIONS OF GLOBAL FINANCIAL CRISIS IN GCC AND SSA REGIONS}

Slow-down in global economic growth adversely affects member countries through lower demand for their exports; decline in oil and non-oil commodities prices; significant decline in official and foreign capital inflows (i.e., official development assistance, grants, foreign direct investment, and workers' remittances); worsening their internal and external balances, slow economic growth and set back in terms of achieving the millennium development goals (MDGs). Due to ongoing global financial turbulence, world economic growth decelerated from 4.2 percent in 2007 to 2.6 percent in 2008 and is projected to decline to negative 0.4 percent in 2009-for the first time in 60 years. Similarly, output growth in advanced countries decelerated from 2.6 percent in 2007 to 0.9 percent in 2008 and is projected to decline to negative 2.1 percent in 2009 while economic growth in developing countries decelerated from 7.8 percent to 6 percent and 3.2 percent, respectively, during the same period (Figure 1).

Fig. 1. Global Output Growth and Oil and Non-oil Commodity Prices (Percent Change, Annual)

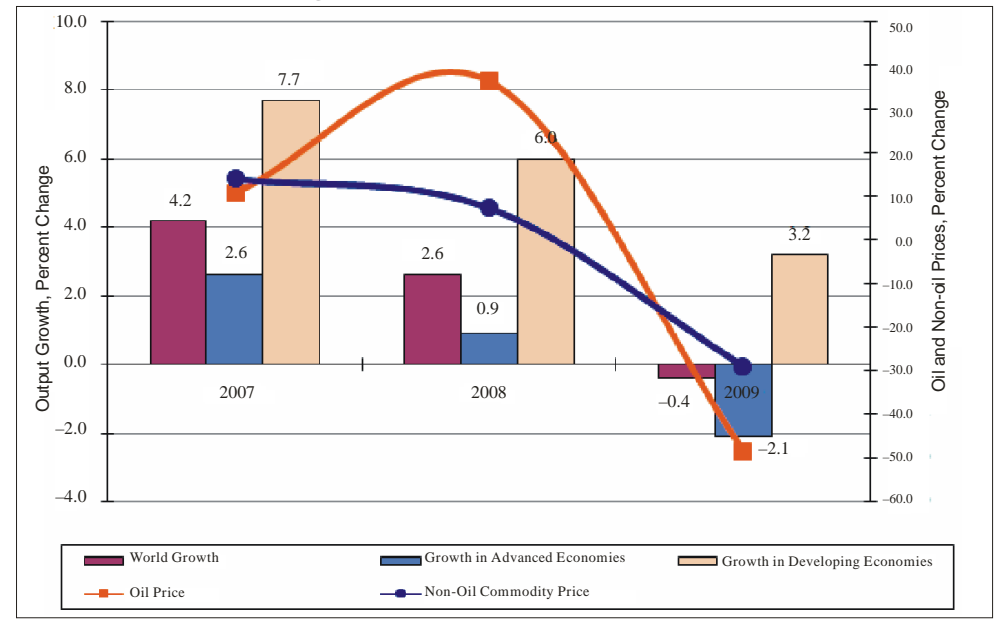

${ }^{3}$ The Gulf Cooperation Council includes Bahrain, Kuwait, Oman, Qatar, Saudi Arabia, and UAE.

${ }^{4}$ Sub-Saharan Africa includes Benin, Burkina Faso, Cameroon, Chad, Comoros, Côte d'Ivoire, Djibouti, Gabon, Gambia, Guinea, Guinea-Bissau, Mali, Mauritania, Mozambique, Niger, Nigeria, Senegal, Sierra Leone, Somalia, Sudan, Togo, and Uganda. 
The second key global factor affecting growth prospects of member countries in GCC and SSA is the plunging prices of oil-and non-oil commodities produced by these countries. The oil price, which increased by 36.4 percent in 2008 (over 2007) is projected to decline by 48.5 percent in 2009. Similarly, weakening global demand is depressing commodity prices and creating deflationary conditions around the globe. The non-oil commodity prices, which increased by 7.4 percent in 2008, are projected to decline sharply by 29.1 percent in 2009 (Figure 1). Due to declining prices and contraction in world output, IDB member countries in GCC and SSA regions, which already felt firstand second order impacts during 2008, are likely to face more severe impacts in 2009.

\section{FIRST-ORDER IMPACTS OF GLOBAL FINANCIAL CRISIS IN GCC AND SSA REGIONS}

The immediate and first-order impact of global financial crisis is felt in member countries in terms of vulnerability of the banking sector, steep fall in stock markets indices, volatility in exchange rate markets, and significant decline in prices of oil and non-oil commodities produced by member countries.

\section{(a) Banking Sector}

\section{(i) GCC Region}

GCC as one of the biggest markets having an estimated \$1.5 - 2 trillion net foreign assets, which could reach to $\$ 7$ trillion by 2012 . The overall foreign holdings represented 225 percent of the GCC's gross domestic product. The UAE, Saudi Arabia, and Kuwait account for the bulk of the GCC foreign asset holdings. These massive funds are placed in the international financial system by way of direct investments in banking sector, stock exchange markets, telecoms, real estate, construction and infrastructure in the USA, Europe, Asia, and the Arab region. ${ }^{5}$ Evidently, in the wake of on-going crisis, the GCC countries are concerned about the depreciation in the values of their assets.

Although, commercial banks in GCC region have strong assets of \$1.3 trillion, the seizing of global credit market, lower oil prices, falling stock markets, and incipient outflows from banks' deposits created unexpected challenges for the GCC banking sector in terms of their business growth, profitability, asset quality and liquidity. The anticipated economic slowdown and tighter liquidity in the region's financial markets may dampen the performance of GCC banks in the coming years. Further, eighteen regional banks have been downgraded by Fitch and six banks by Standard and Poors, which is likely to make it difficult for raising funds. ${ }^{6}$

The systemic threats to the GCC banking sector is appearing in terms of a rise in the cost of funding and tight liquidity. Due to tighter liquidity, the GCC banks are moving to credit market to refinance themselves. As a result of increasing liquidity demand, the cost of credit has risen significantly. In particular, the weighted average credit spread on GCC Conventional Financial Services US Dollar Bond Index (GCFI) ${ }^{7}$

${ }^{5}$ Report by Institute for International Finance (IIF), Washington, (Saudi Gazette, 1st November 2008).

${ }^{6}$ Millennium Finance Corporation, GCC Year Book 2009.

${ }^{7}$ The most common indicator for cost of credit used is HSBC/ DIFX GCC Conventional Financial Services US Dollar Bond Index (GCFI), which is designed as a replicable benchmark tracking the return of an emerging GCC Conventional Financial Services bon portfolio. It consists of USD/ GBP/ JPY/ EURdenominated fixed/ floating rate vanilla conventional bonds. 
above LIBOR was 259 basis points on $1^{\text {st }}$ September 2008. Since the explosion of global financial crisis, this spread increased tremendously by about four times (i.e., 947 basis points) on 24 March 2009 (Figure 2).

Fig. 2. GCC Banks US Dollar Bond Index (GCFI): Spread Over LIBOR (25 March 2008 to 24 March 2009)

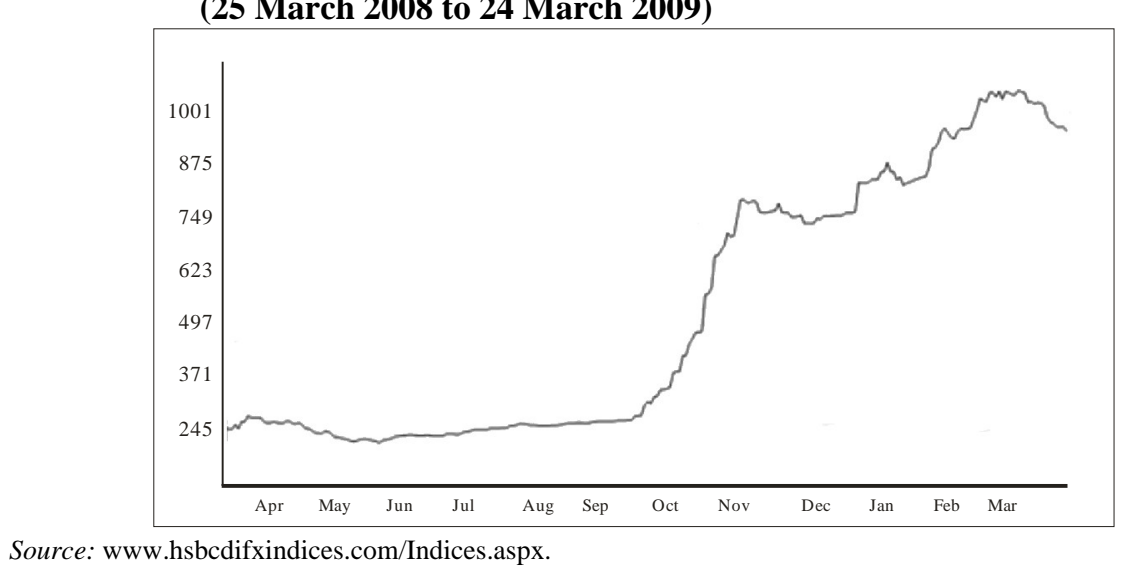

The majority of assets of the GCC region are not managed by banks but by Sovereign Wealth Funds (SWFs) like Abu Dhabi Investment Authority or Kuwait Investment Authority. The SWFs invest their funds in a broad range of securities, but public data about the size and composition of their assets are not available, and one has to rely on estimates. According to the estimates, the level of Sovereign Wealth Funds is between $\$ 1$ trillion to $\$ 1.5$ trillion. ${ }^{8}$ With a considerable estimated equity component of 40 percent and more, the losses due to global financial crisis must have hurt the GCC region's SWFs to a considerable extent. In the space of just a few months, SWFs from the GCC region have likely lost billions of dollars by recapitalising the Western banks.

The banking sector is cushioned by the GCC governments' support and proactive measures by the central banks. ${ }^{9}$ Some of the key measures taken since early September 2008 are as follows:

- The Saudi Arabian Monetary Authority reduced the Repo rate four times, bringing it down from 5.5 percent to 2.5 percent, and reduced its reserve Repo rate from 2 percent to 1.5 percent. It brought down the capital reserve requirement for commercial banks from 13 percent to 7 percent. It also injected $\$ 3$ billion into the banking system to improve liquidity and guaranteed deposits.

- UAE reduced its benchmark Repo rate to 1.5 percent. The UAE Government also injected $\$ 32$ billion into the banking system as long-term deposits to ease liquidity pressure.

- Central Bank of Kuwait reduced its discount rate by 50 basis points to 3.75 percent and reduced its one month Repo rate from 3 percent to 2.5 percent and

${ }^{8}$ IDB Current Information Note No. 101 on "Sovereign Wealth Funds", reported the SWFs in GCC region between $\$ 1$ trillion (lower limit) to $\$ 1.6$ trillion (upper limit).

${ }^{9}$ For more detail, see GCC Year Book, March 2009. 
capital reserve requirement from 20 percent to 18 percent. It also provided guaranteeing of deposits.

- Oman Central Bank reduced its Repo rate by 89 basis points to 1.53 percent and cut the capital reserve requirement from 8 percent to 5 percent.

- Central Bank of Bahrain also reduced its Repo rate by 75 basis points to 2.5 percent.

Islamic banks and financial institutions have remained largely insulated from the first-order impact of the global financial crisis. This is mainly because of their insulation from 'toxic' financial assets; Shariah-compliant debt instruments; and prohibition of speculative activities. However, a major downside risk to growth and profitability prospects of Islamic banks arises from the projected global economic recession during 2009 that will inevitability heighten risk and slowdown credit off-take by businesses across the developing countries.

During the last decade, the Islamic financial services industry had grown rapidly with annual growth of between 10 percent and 20 percent, while the number of Islamic finance institutions reached 300 in over 75 countries in $2008 .{ }^{10}$ The scope of Islamic finance business had also expanded to more sophisticated Shariah-compliant financial products. Clearly, the global financial meltdown has created challenges as well as opportunities for the industry. Shariah-compliant assets worldwide were estimated to have reached $\$ 800$ billion by the end of 2007 , a phenomenal growth in just seven years from $\$ 140$ billion in 2000. According to a recent report by McKinsey and Co, ${ }^{11}$ Shariah-compliant assets are projected to reach $\$ 1$ trillion by $2010 .{ }^{12}$ For the same period, the assets of the Islamic banks in the GCC region grew by 47.5 percent over 2007 to reach $\$ 262.7$ billion in November 2008, while in the Asia region they grew by 32.3 percent to reach $\$ 67.1$ billion during the same period. ${ }^{13}$

The global exposure of Islamic financial industry to financial services and real estate sector is estimated at over 40 percent. $^{14}$ In the current global economic environment, such a high level of sectoral concentration will naturally affect the growth prospects of non-bank segments of the Islamic financial industry. For instance, total issuance of Sukuk stood at around $\$ 14.6$ billion in 2008, less than half of nearly $\$ 33$ billion recorded in 2007..$^{15}$ The sharp decline in Sukuk issuance was witnessed in the fourth quarter of 2008. This was caused by the Accounting and Auditing Organisation for Islamic Financial Institutions ruling on the Shariah-compliance of some Sukuk structures in January 2008, as well as by factors related to global financial crisis such as drying up of liquidity and widening of credit spreads even for prime borrowers. The weighted average credit spread over LIBOR on Sukuk US Dollar Bond went up by more than four times (i.e., from 296 basis points on first September 2008 to 1006 basis point on 24 March 2009 (Figure 3).

\footnotetext{
${ }^{10}$ 'Islamic Finance: 'Opportunities and Challenges', published by Gulf One Investment Bank Research Bulletin, Vol. 1, No. 12, December 2008.

${ }^{11}$ McKinsey and Co. Report, December 2007.

${ }^{12}$ According to Moody's projections, Shariah-compliant assets worldwide are expected to reach $\$ 4$ trillion by 2015 .

${ }^{13}$ 'Top-500 Islamic Financial Institutions', Supplement published by The Banker Magazine, November 2008.

${ }^{14}$ 'Islamic Finance: Opportunities and Challenges', ibid.

${ }^{15}$ 'Islamic Finance: Opportunities and Challenges', ibid.
} 
Fig. 3. Sukuk US Dollar Bond Index (SKBI): Spread Over LIBOR (25 March 2008 to 24 March 2009)

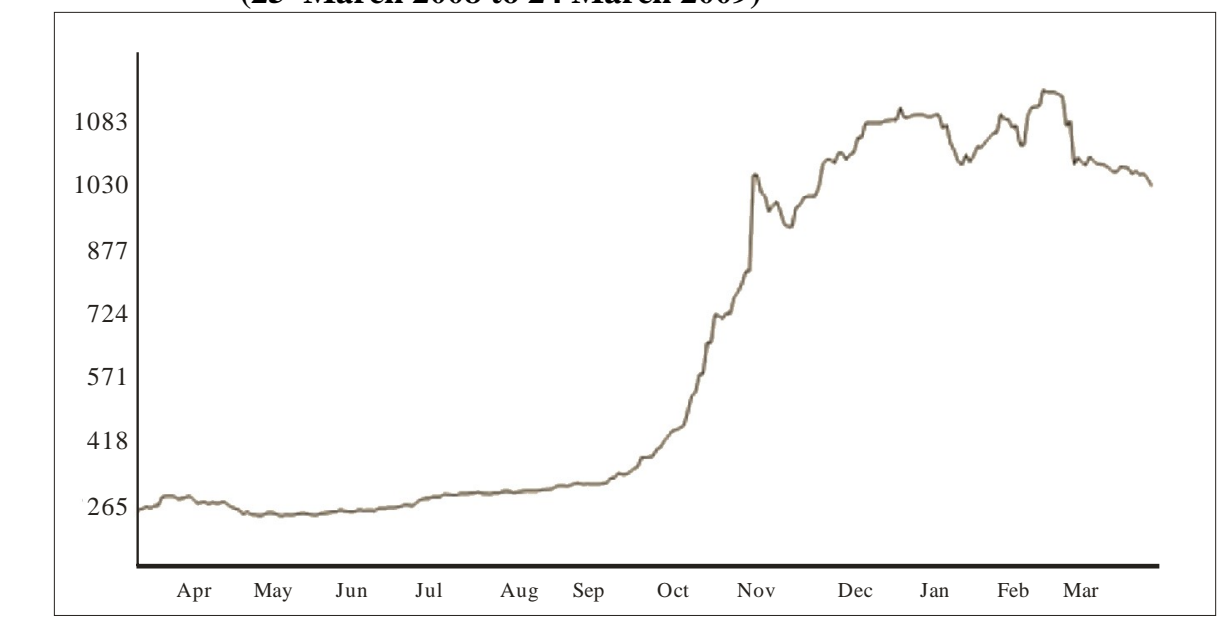

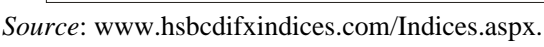

\section{(ii) SSA Region}

Financial systems in SSA region are less integrated with global financial markets and thus are less vulnerable. They are generally not exposed to risks arising from complex derivative instruments and have not relied substantially on foreign borrowing to finance their operations. The foreign ownership is rather limited. As a result, financial institutions in the region have by and large remained unaffected and domestic money markets are generally functioning normally. However, if the global financial turbulence deepens further, the banking sector may be weakened through a decline in the quality of their credit portfolios, losses on other financial assets, such as deposits with troubled foreign correspondent banks, or capital repatriations by troubled parent banks, which are often foreign-owned. Further, the credit line for the banking sector in the SSA region has started shrinking while raising funds for new development projects will not be easy. The international banks are likely to cut-off export and imports trade lines for the SSA region.

\section{(b) Stock Markets}

\section{(i) GCC Region}

GCC stock markets have suffered much more compared to stock markets of the US and other developed countries. Since the onset of the global financial crisis in early September 2008, GCC stock markets have posted major losses. Qatar's overall stock market index plummeted by 54.5 percent, followed by Kuwait (53.8 percent), Oman (50.6 percent), Saudi Arabia (49.7 percent), UAE (Abu Dhabi) 45.7 percent, and Bahrain 41.2 percent between 1st September 2008 and 18 March 2009 (Figure 4). 
Fig. 4. Overall Stock Market Index GCC Countries, 2008 and 2009 (Percent Change)

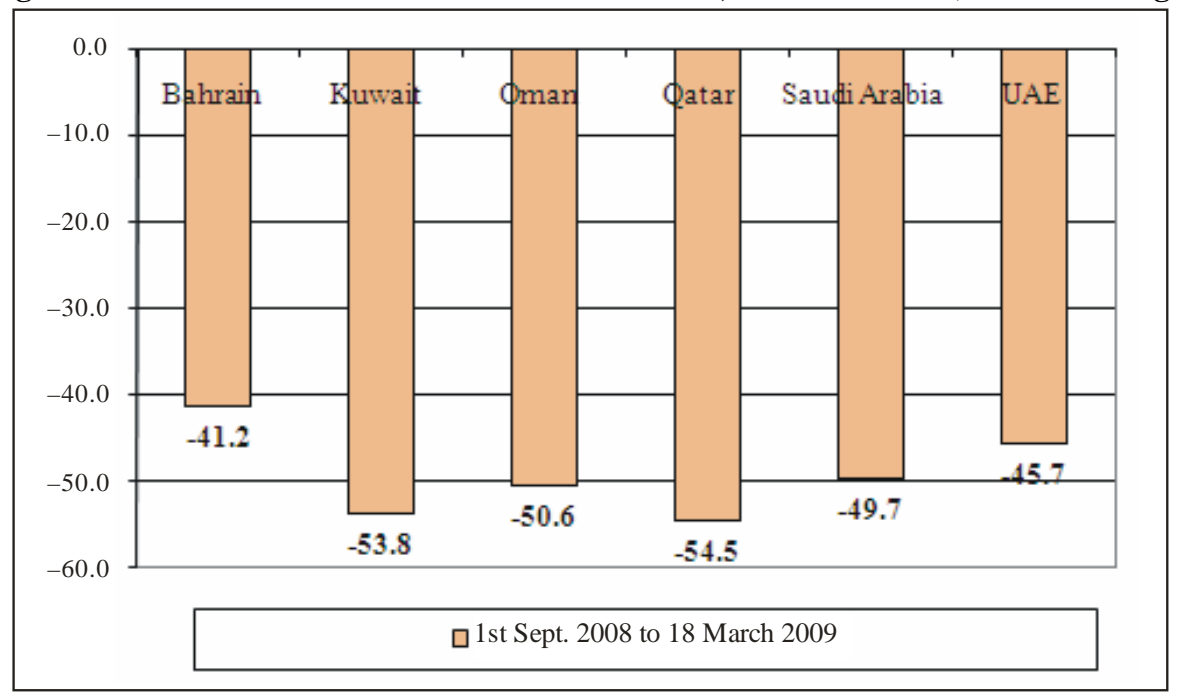

Source: Website of each respective country.

In order to draw 'right' lessons from the current turmoil, it is important to understand the underlying reasons for the boom-bust stock markets performance in the GCC region. Since the GCC currencies are 'more or less' pegged to the US dollar, the accommodative monetary policy of the US Federal Reserve was also followed by their central banks. This led to an explosive growth in the banking liquidity, which provided an environment for investors in the GCC region to finance through bank borrowings their growing demand for stock market shares and real estate investments.

Thus, an 'illusion' of wealth effect is created which fuels a rise in household wealth and stock prices to rise sharply. Following the onset of global financial crisis, as a consequence of major market correction in the GCC region-'stock market bubble'investors are forced to cut their spending or liquidate other assets in order to repay bank debts. A high level of delinquencies by such investors or households adds to a deterioration in banks' balance sheets. The earlier GCC experience of steep rise in share prices between 2004 to 2006 once again demonstrates the universal experience that credit-driven rise in share prices are 'short-lived' while only economic growth can generate a sustained net inflow of funds to drive 'real' stock market performance.

\section{(ii) SSA Region}

The direct impact of financial meltdown is being felt in the SSA region's stock exchange markets as they have moved in the same direction as stock markets in developed and emerging economies. This is contrary to earlier expectation that the global crisis may divert capital flows towards SSA region. It seems that investors are shying away from regional stock markets that are perceived to be riskier and are attempting to repatriate their funds to safer places. Between September 1st 2008 and 16 March 2009, the composite index of securities exchange of 8 countries of the West African Economic and Monetary Union fell by 33.8 percent. This shows that volatility in the stock market is 
encouraging investors to shift their capital to safer places. The stock market has also lost more than 30 percent of market capitalisation since 1st September 2008.

With regard to sector-wise stock market indices, since the beginning of global financial turmoil, the agriculture sector experienced steepest decline (55.5 percent), followed by financial (35.8 percent), distribution (35 percent), public utilities (30.6 percent), and industry (25.3 percent), while transportation ( 23.5 percent) was the least affected sector during the period 1st September 2008 to 16 March 2009 (Figure 5).

Fig. 5. Regional Stock Market Indices in UEMOA (Percent Change on 16 March 2009 Over 1st Sept. 2008)

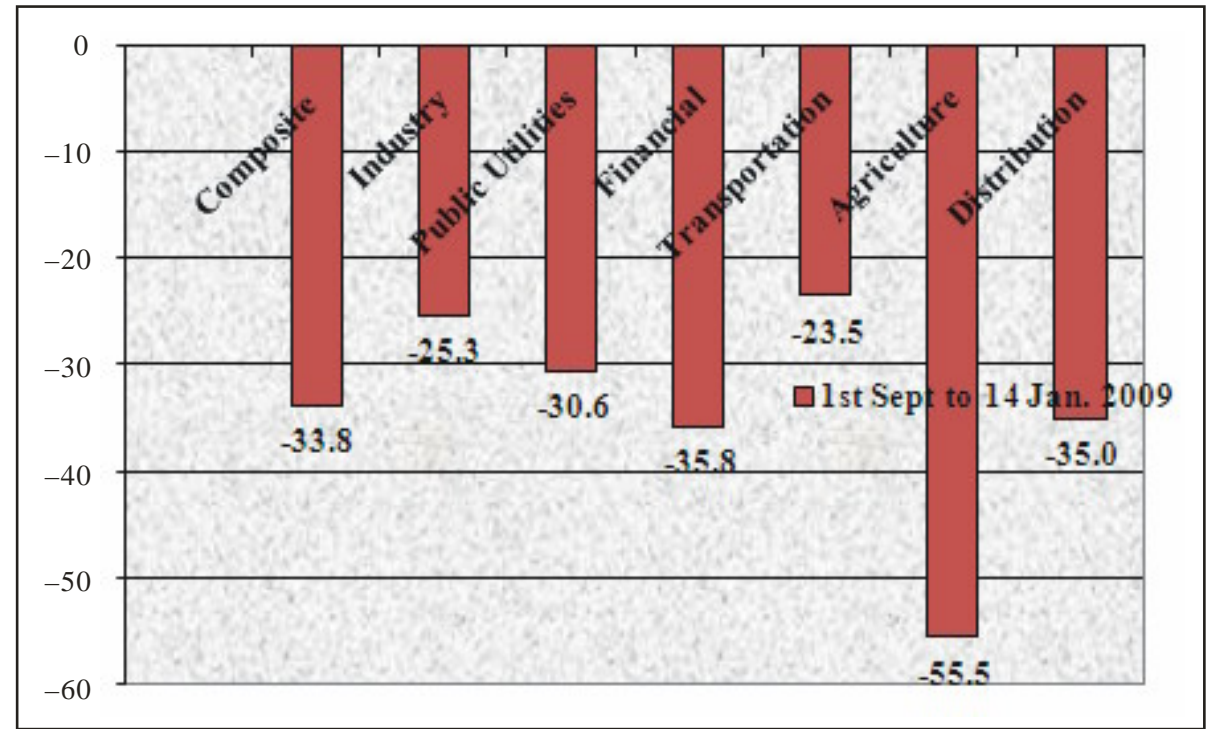

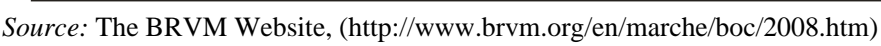

1/ The West African Economic and Monetary Union (UEMOA) includes Bénin, Burkina Faso, Côted'Ivoire, Guinea Bissau, Mali, Niger,. Senegal, and Togo.

IDB member countries in Sub-Saharan Africa also experienced reduced or reverse portfolio inflows as investors are likely to flee into more liquid or safer assets. However, during the course of 2008 , portfolio inflows have come under some pressure as global liquidity has tightened and exchange rates and capital markets have become more volatile. Due to the perceived risk of investing in local-currency denominated assets, investors have become more concerned about an increase in political and macroeconomic risks and the liquidity of their assets in the SSA region. The intensification of global financial market turbulence is likely to further increase investor's preference for highly liquid and high-quality assets and may further affect portfolio investment in the SSA region.

\section{(c) Exchange Rate Markets}

Member countries in SSA region have different exchange rate regimes. In particular, the CFA Franc Zone (including 11 member countries) has fixed exchange rate with respect to Euro. The global financial crisis is also being felt in 
the foreign exchange markets of SSA region. The exchange rate markets have come under severe pressure since early September 2008 because a decline of international capital flows has made the exchange rate markets more volatile, in particular, against currencies of major trading partners (USA, European Union, China and India). Since 1st September 2008, currencies of all member countries in SSA region have depreciated against US dollar and Chinese Yuan, which will have adverse effects on trade and foreign capital flows. However, exchange rates in some of the member countries in the SSA region appreciated against Euro and Indian rupees as these currencies have also come under pressure since the beginning of September 2008 (Table1).

Table 1

Volatility in Nominal Exchange Rate in SSA Region Between 1st September 2008 and 16 March 2009

\begin{tabular}{|c|c|c|c|c|}
\hline & \multirow{3}{*}{$\begin{array}{l}\text { LCU/US\$ } \\
\% \text { Change }\end{array}$} & \multicolumn{3}{|c|}{ LCU/Chinese } \\
\hline & & LCU/Euro & Yuan & LCU/Indian Rs \\
\hline & & $\%$ Change & & $\%$ Change \\
\hline Mozambique (Meticle, MZM) & -8.7 & -3.5 & -8.6 & 9.6 \\
\hline Guinea (Franc) & -0.6 & -11.3 & -0.6 & 19.3 \\
\hline Sierra Leone (Leone, SLL) & -4.3 & -7.9 & -4.3 & 14.9 \\
\hline Uganda (Shilling, UGX) & -19.7 & 9.7 & -19.6 & -3.5 \\
\hline Somalia (Shilling, SSO) & 0.1 & -12.0 & 0.2 & 20.2 \\
\hline Comoros (Franc, KMF) & -13.3 & 0.0 & -12.2 & 5.4 \\
\hline Mauritania (Ouguia, MRO) & -9.0 & 2.4 & -14.0 & 3.3 \\
\hline Sudan (Dinar, SDD) & -7.7 & -4.6 & -7.6 & 10.9 \\
\hline Djibouti (Franc) & -0.7 & -11.2 & -0.7 & 19.2 \\
\hline Nigeria (Naira.NGN) & -20.7 & 11.1 & -20.7 & -4.8 \\
\hline Gambia (Bambian Dalasi GMD) & -16.0 & 4.9 & -15.9 & 0.9 \\
\hline CFA Franc Zone & -12.2 & 0.0 & -12.1 & 5.5 \\
\hline
\end{tabular}

\section{(d) International Prices of Oil and Non-oil Commodities}

\section{(i) Oil price and Fiscal Vulnerabilities of GCC Region}

With crude oil prices having declined significantly from the record level of $\$ 147$ per barrel in July 2008 to $\$ 40$ per barrel in December 2008 and the expected slowing down in the global economy, risks to the internal and external balances of the GCC countries have increased significantly. Figure 6 shows the break-even crude oil price (i.e., the price at which a GCC country would achieve a fiscal balance). Among GCC countries, the break-even oil price per barrel is highest for Oman $\$ 77$, followed by Bahrain $\$ 75$, Saudi Arabia $\$ 49$, Kuwait $\$ 33$, Qatar $\$ 24$, while UAE has the lowest break-even oil price of $\$ 23$ per barrel in order to achieve the fiscal balance. It implies that, at the level of price of $\$ 40$ per barrel, there is a risk that the fiscal balances of Oman, Bahrain and Saudi Arabia may turn into negative due to lower oil revenues. 
Fig. 6. Break-Even Crude Oil Price for Fiscal Balance and Spot Crude Oil Price, 2008

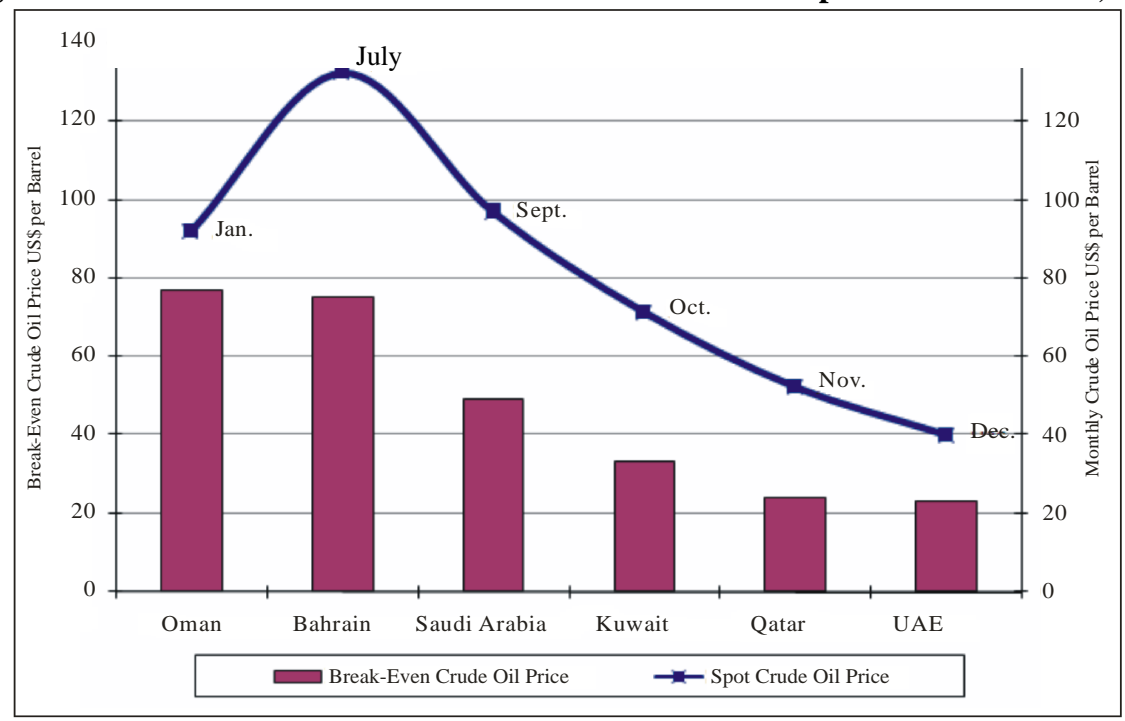

\section{(ii) Sharp Decline in International Prices of Major Commodities Produced by SSA Region}

The oil-exporting countries in SSA region, (Cameroon, Chad, Gabon, Nigeria and Sudan) are adversely affected by the sharp decline in petroleum prices, representing 62 percent decline between September 2008 and February 2009). Since the start of global financial turbulence, international prices of major products produced in SSA region started to decline sharply. The decline in the prices in February 2009 (over August 2008) was between 5 percent to 52 percent (Table 2).

Table 2

International Prices of Major Commodities Produced in Sub-saharan Africa

\begin{tabular}{lc}
\hline Commodity & \% Change in Prices (February 2009 \\
Over August 2008)
\end{tabular}




\section{SECOND-ORDER IMPACTS OF GLOBAL FINANCIAL CRISIS ON ECONOMIC OUTLOOK OF GCC AND SSA REGIONS}

If the global financial crisis deepens further, its second-order impacts are likely to be more severe. These impacts are being felt in external sector in terms of decline in foreign capital inflows (i.e., workers' remittances, foreign direct investment, official development assistance, and official grants) and deterioration in terms of trade, which are adversely affecting the current account balances of member countries. Second, lower prices of oil and non-oil commodities affect government revenues, consequently the fiscal deficits worsened in most member countries. Third, worsening external and fiscal balances result in slowing down of economic growth. Finally, if the financial turbulence further deepens, there will also be adverse social impacts (i.e., rising poverty and unemployment) in member countries.

\section{(a) External Sector}

\section{(i) Outward Remittances from GCC Region}

Expatriate workers not only play a major role in the economic development of GCC countries but are also a source of remittances to their countries of origin. In 2007, the outward remittances from the four GCC countries (Saudi Arabia, Kuwait, Oman, and Bahrain) totaled $\$ 25$ billion. In the face of expected slowdown of economic activity in the GCC countries, many IDB member countries are likely to experience widening gaps in their balance of payments position along with adverse consequences for incomes/poverty levels of remittance-recipient households.

\section{(ii) Flows of Workers' Remittances into SSA Region}

According to the World Bank, workers' remittances in developing countries are projected to decline from $\$ 283$ billion in 2008 to $\$ 267$ billion in 2009 , down by 5.7 percent, while in Sub-Saharan Africa, workers' remittances are projected to decline by 6.8 percent in 2009. ${ }^{16}$ Remittances in many member countries in this region are the major source of funding their current account deficits. The dependence of member countries on remittances has sharply increased over the past decade. In 2007, diasporas of 20 member countries in Sub-Saharan Africa sent back $\$ 14.4$ billion, representing 4.3 percent of their GDP. However, recent heightened financial turbulence raises the risk of a decline in resource flows to SSA region in the form of workers' remittances.

\section{(iii) FDI Outflows and Inflows from / to GCC Region}

Total FDI outflows from six GCC countries reached about \$28.3 billion in 2007. In recent years, many member countries have been recipients of FDI inflows from GCC countries, particularly in their major infrastructure projects. With lower oil revenues and slower economic activity, it is likely that FDI outflows from GCC countries will fall in

${ }^{16}$ World Bank, “Migration and Development Brief” (11 November 2008). 
the coming years. At the same, the FDI flows into GCC region amounted to $\$ 43$ billion in 2007, which are also likely to be affected if the ongoing financial and economic crises prolong.

\section{(iv) FDI Flows to SSA Region}

Foreign direct investment had supported the remarkable economic growth achieved by the SSA region during the last decade. In 2007, IDB member countries in SSA region received FDI flows of $\$ 19.2$ billion, representing 5.7 percent of their GDP. The FDI in member countries was attracted by the services sector particularly telecommunications. However, tightening of global credit conditions is likely to lower FDI flows to the region. Since a substantial and growing part of FDI flows in the SSA region comes from China, India, and the Gulf countries, the reversal of such flows by the risk-averse investors can make the region more vulnerable.

\section{(v) ODA to SSA Region}

Many member countries in SSA region expect that official development assistance (ODA) will slow down or postpone promised increases as crisis-hit rich countries are reassessing their fiscal priorities and aid commitments since the advent of ongoing financial turmoil. Even before the financial crisis, ODA donors were not on track to achieve the target. In 2006, 17.7 percent ( $\$ 23.8$ billion) of aggregate net ODA was disbursed to member countries in SSA region, which declined to 11 percent ( $\$ 15.9$ billion) in 2007. Therefore, any further reduction in ODA will put more pressure on domestic resource mobilisation in order to finance the external account deficits of member countries in the region.

\section{(vi) External Debt Distress in SSA Region}

In the last decade, sustained economic growth and sound economic policies had helped most Sub-Saharan African member countries to achieve debt sustainability. According to the IMF, fuel and food crises have already pushed 6 member countries (Comoros, Cote d' Ivoire, Guinea, Guinea Bissau, Sudan, and Togo) into debt distress (i.e. countries already having debt repayments difficulties), while 3 member countries (Burkina Faso, Djibouti, and Gambia) are at high risk (with one or more debt burden indicators breaching the thresholds, defined in terms of net present value of external debt and debt servicing as percent of exports, GDP and revenue) (Table 3). Therefore, if the global financial deepens, more member countries are likely to find themselves in debt distress. 
Table 3

Debt Sustainability Analysis of Sub-Saharan Africa (Last Updated, 2 March 2009)

\begin{tabular}{|c|c|c|}
\hline & Risk of Debt Repayment & $\begin{array}{l}\text { Minimum Grant Element for } \\
\text { External Financing }(\%) \\
\end{array}$ \\
\hline \multicolumn{3}{|l|}{ In Debt Distress } \\
\hline Comoros & In Debt Distress & 50 \\
\hline Cote d'Ivoire & In Debt Distress & 35 \\
\hline Guinea & In Debt Distress & 35 \\
\hline Guinea-Bissau & In Debt Distress & 50 \\
\hline Sudan & In Debt Distress & $*$ \\
\hline Togo & In Debt Distress & 35 \\
\hline \multicolumn{3}{|l|}{ High Risk } \\
\hline Burkina Faso & High Risk & 35 \\
\hline Djibouti & High Risk & n.a. \\
\hline Gambia & High Risk & 45 \\
\hline \multicolumn{3}{|l|}{ Moderate Risk } \\
\hline Benin & Moderate Risk & 35 \\
\hline Chad & Moderate Risk & $*$ \\
\hline Mauritania & Moderate Risk & 35 \\
\hline Niger & Moderate Risk & 35 \\
\hline Sierra Leone & Moderate Risk & 35 \\
\hline \multicolumn{3}{|l|}{ Low Risk } \\
\hline Cameroon & Low Risk & $*$ \\
\hline Mali & Low Risk & 35 \\
\hline Mozambique & Low Risk & 35 \\
\hline Nigeria & Low Risk & $*$ \\
\hline Senegal & Low Risk & 35 \\
\hline Uganda & Low Risk & 35 \\
\hline
\end{tabular}

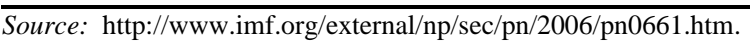

Low Risk, when all the debt burden indicators are well below the thresholds.

Moderate Risk, when debt burden indicators are below the thresholds but they be breached if there are external shocks or abrupt changes in macroeconomic policy.

High Risk, when one or more debt burden indicators breach the thresholds.

In Debt Distress, when the country is already having repayment difficulties.

*There is no binding minimum concessionality requirement for countries which not under the IMF

Poverty Reduction and Growth Facility (PRGF).

\section{(vii) Current Account Balance of GCC Region}

All the GCC countries have posted higher current account surpluses in 2008 compared to 2007 , mainly due to the rising oil revenues. Consequently, the combined current account surplus of the GCC region reached 31.6 percent of GDP in 2008, which is projected to decline to 25 percent in 2009, reflecting the decline in oil price (Figure 7). 
Fig. 7. Current Account Balance of GCC Region (\% of GDP)

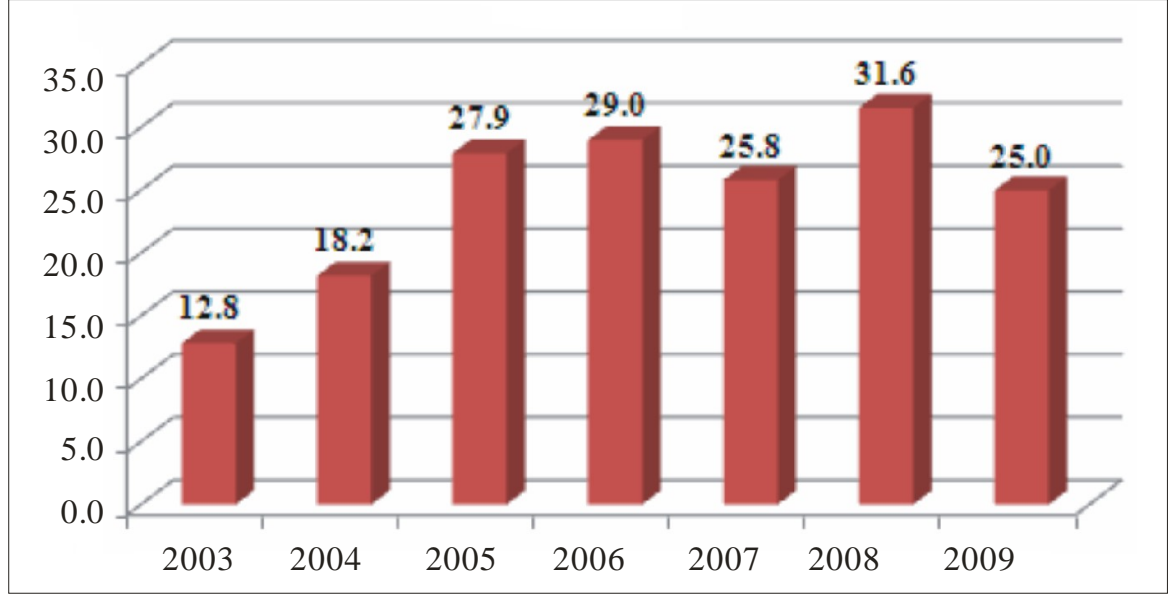

Source: Islamic Development Bank (March 2009).

\section{(viii) Current Account Balance of SSA Region}

The SSA region experienced a current account surplus of 7.5 percent of GDP in 2008, due to higher prices of oil and non-oil commodities during the first half of 2008. However, the region's current account surplus is projected to turn into deficit in 2009, depending upon how deep and long the economic recession prevails (Figure 8). In particular, lower global economic growth and deterioration in terms of trade are projected to reduce the demand for exports of goods and services in SSA region. Increasing trade links with the European Union, China, India and other emerging markets have also helped the SSA region in achieving sustainable growth during the last decade. Therefore, due to slowdown in output growth and consequently lower demand in these countries will have adverse impacts on the regional exports prospects.

Fig. 8. Current Account Balance of SSA Region (\% of GDP)

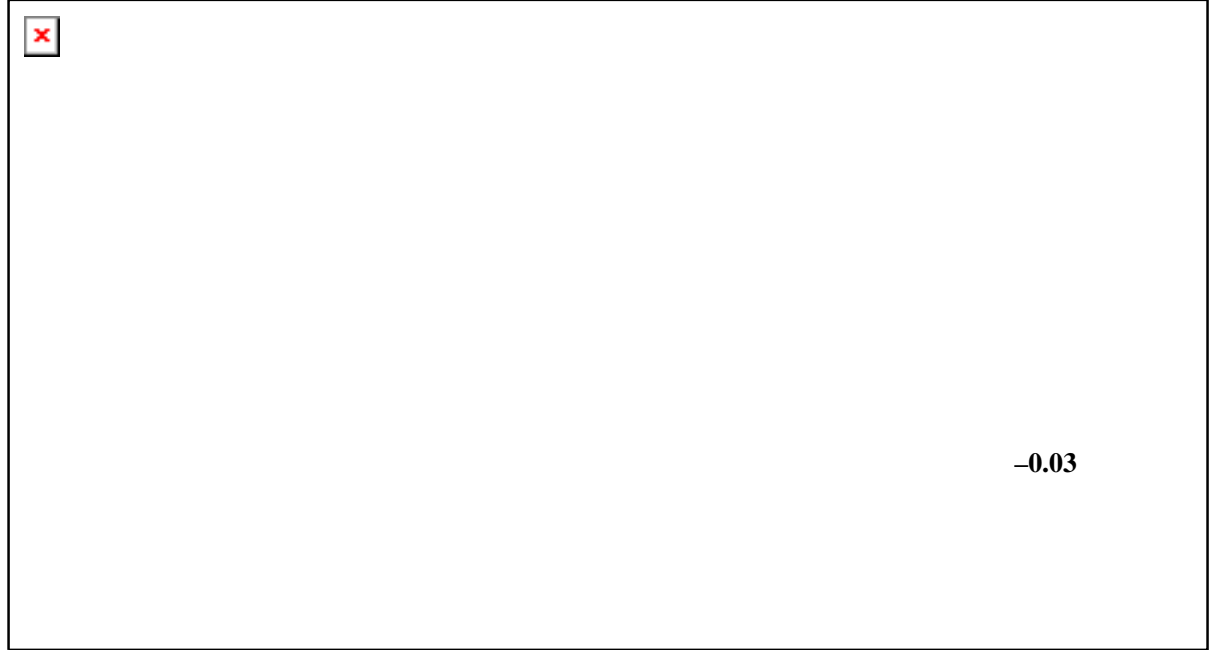

Source: Islamic Development Bank (March 2009). 


\section{(c) Economic Growth}

\section{(i) GCC Region}

The GCC region experienced real GDP growth of above 5 percent during the last six years. In particular, the region witnessed a remarkable growth of 6.7 percent due to higher commodity prices and strong domestic demand. Despite the subdued global economic environment, the real GDP in 2009 is projected to grow by 4.2 percent in the GCC countries (Figure 9). Slow GDP growth will be due to deceleration in both oil and non-oil GDP, reflecting spillovers from the global financial crisis as well as lower oil prices in the region. Most of the growth is expected to come from the non-oil sector as the GCC countries have made a lot of efforts on the diversification of their economies during the last few years. It is worth noting that the oil and gas sector contributed about 56 percent of nominal GDP for the GCC economies in 2008. With the declining oil prices, this share is expected to decline to 39 percent in $2009 .{ }^{17}$

Fig. 9. Real GDP Growth in GCC Region (Annual Change, in Percent)

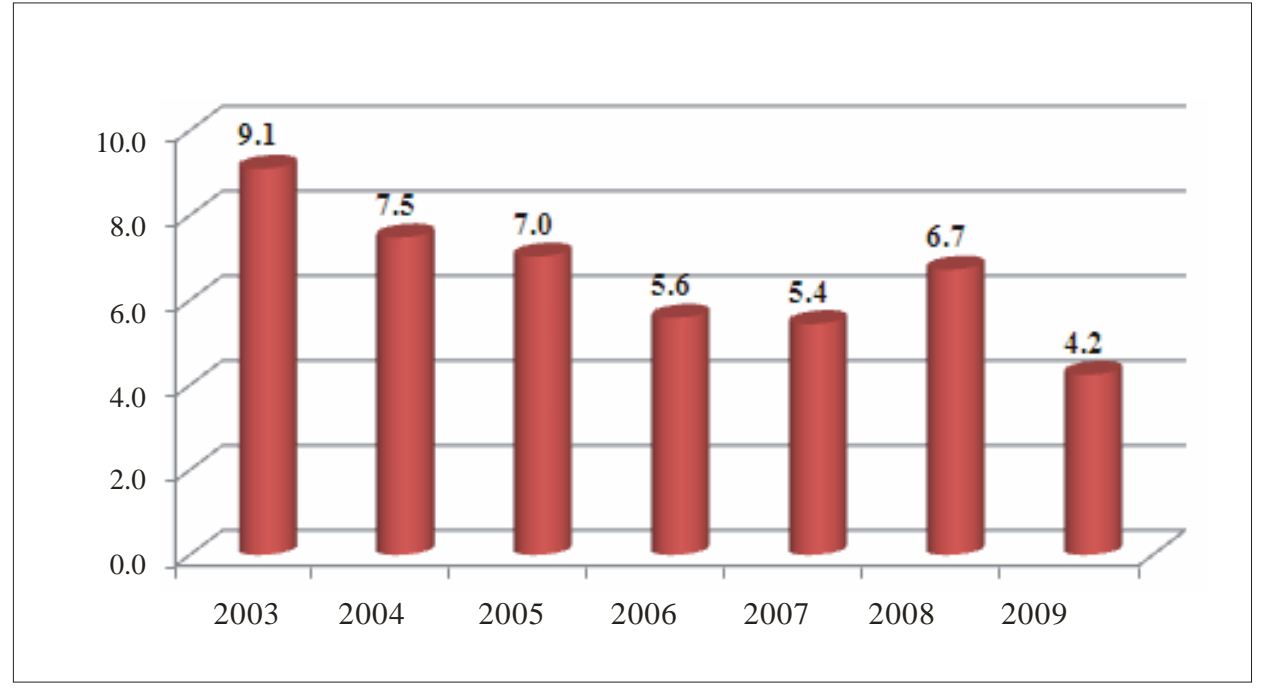

Source: Islamic Development Bank (2009).

The demand for crude oil and products of the GCC's heavy industries like petrochemicals and aluminum is expected to suffer. Besides, financing for large ongoing mega projects in the region will not be as readily available as in the past and might affect the cost structure or even the feasibility of some mega industrial projects. The real estate sector is equally being hit especially in more heated markets like Dubai, where it has relied heavily on debt financing and speculation. The high demand by the people of the GCC countries for imported as well as domestically produced products is likely to decline in the coming years. However, the strategic reserves from the windfall oil revenues of the previous three years may help sustain the region's growth.

\footnotetext{
${ }^{17}$ Millennium Finance Corporation, GCC Year Book 2009 (March 2009).
} 


\section{(ii) SSA Region}

The current global financial crisis has come at a time when a large number of member countries in Sub-Saharan Africa are enjoying high rates of economic growth. In 2008 , the SSA region experienced a growth of 4.9 percent, which is lower than the growth rate of 5.8 percent achieved in 2007. However, the ongoing financial turbulence will have an adverse impact on economic growth in the region as the growth projections for 2009 is 4.5 percent (Figure 10). As a result of financial turbulence, the markets for exports of SSA region are expected to be adversely affected. Therefore, reduced demand for SSA region's exports will dampen its economic growth prospects. According to the World Bank estimates, a 1 percentage point decline in growth in (and export demand from) trading partners reduces GDP growth in Sub-Saharan Africa by about 0.5 percentage point, in addition to any effects from commodity price changes.

Fig. 10. Real GDP Growth in SSA Region (Annual Change, in Percent)

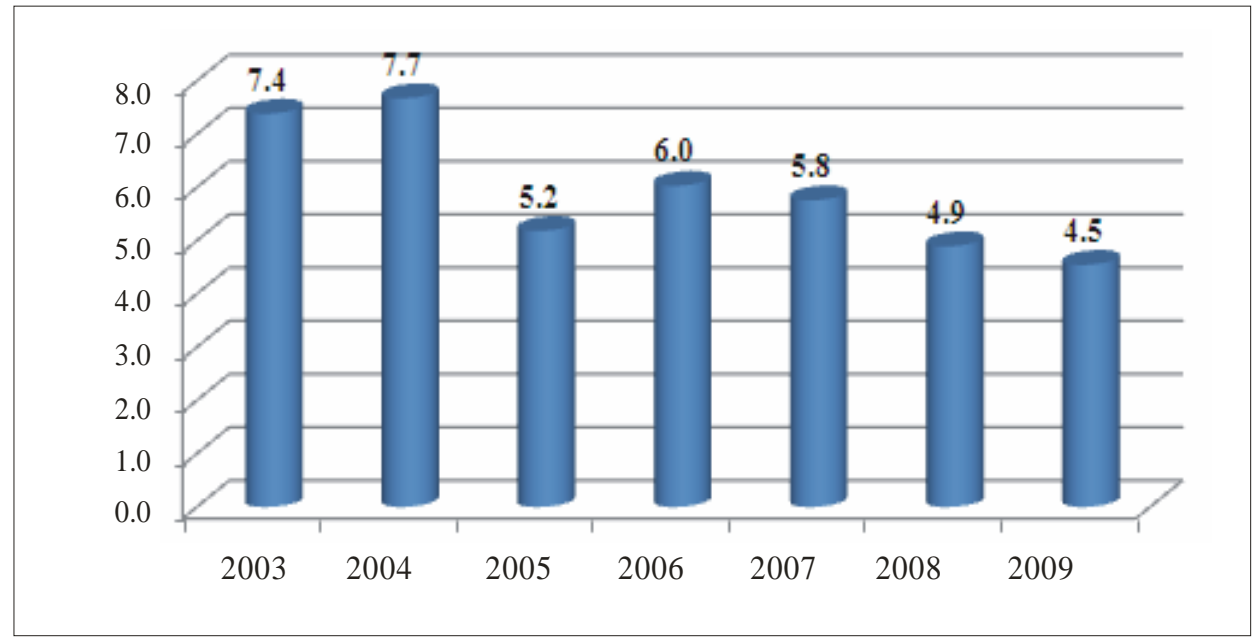

Source: Islamic Development Bank (March 2009).

\section{(d) Social Indicators}

\section{(i) Unemployment}

Young men and women are the greatest assets in any country. They bring energy, talent, and creativity into economies and lay the foundations for future economic development. Currently, most of the IDB member countries, particularly GCC economies are experiencing demographic dividend. In the GCC region, total youth population (both boys and girls) was 5.84 million in 2002, which in 4 years rose to 6.37 million, showing an average growth of 2.27 percent per annum. During the same period, youth employment increased from 1.71 million to 1.84 million, a growth of 1.96 percent per annum. Further, the employment-to-youth population ratio was significantly low at 29.2 percent in 2002 and 28.9 percent in 2006, compared to the world ratio of 47.5 percent and 47.3 percent, respectively. This indicates that about 70 percent of the youth population was not directly involved in 
market-related activities, either because they were unemployed or (more likely) out of the labour force altogether. The scenario highlights the point that unless appropriate and timely policies are formulated by member countries, the demographic transition, instead of dividend, might in fact become a burden, putting an unbearable strain on the national budget and domestic resources. In particular, there is an urgent need to develop strategies aimed at giving young people a chance to make the most of their potential through decent employment. Further, creating equal opportunities for both youth male and female also remains a major challenge in the GCC region. It is extremely important that women's participation in the labour market, in conformity with society's religious norms, continues to grow in such a way that they find themselves productive and are able to contribute to the overall economic wellbeing.

According to a recent IDB study, with the current economic growth, member countries will not be able to achieve the MDG target of full employment by 2015 . This will only be possible if they are able to achieve and maintain real output growth of 8 percent by 2020. With the slowing economic growth, it will be difficult for both public and private sectors to generate new jobs. ${ }^{18}$ The number of unemployed person in 21 SSA member countries increased from 10.5 million in 2003 to 11.7 million in 2006. Most of the IDB member countries in Sub-Saharan Africa are already facing the negative impacts of high food and fuel prices on employment and, the financial crisis will further aggravate this problem. With the slow output growth, reduced exports, and low levels of official and private capital inflows in 2008 and 2009, one can safely predict the adverse impact on employment in SSA region.

\section{(ii) Poverty}

If the ongoing financial turbulence transforms into human crisis in the developing world, it will have severe impact on the poor people in the SSA region. According to an IDB study, poverty in Sub-Saharan African member countries has already been increasing over time as the population living below poverty line (under \$1 per day) went up from 52.6 percent in 1990 to 55.6 percent in $2004 .{ }^{19}$ The slow economic growth in SSA region is likely to aggravate the poverty situation. According to the World Bank estimates, the number of poor pushed into poverty in 2008 was $130-155$ million as a result of the food and fuel crises and the spreading global financial and economic crisis will trap 53 million more people in poverty in developing countries.

\section{(iii) Progress in Other MDGs}

The GCC member countries are on track in most of the MDGs. However, slow economic growth and lower levels of official and private capital flows are likely to have an adverse impact on the progress towards the achievements of MDGs in member countries in Sub-Saharan Africa.

${ }^{18}$ IDB study (November 2008), "The Challenge of Unemployment in IDB Member Countries: Can They Achieve the Target of Full Employment by 2015?".

${ }^{19}$ IDB Study (July 2008) "Achieving the Targets of IDB 1440H Vision and the Millennium Development Goals: Scorecard for Member Countries". 


\section{IDB GROUP'S RESPONSES TO THE RECENT CRISES}

Given the enormity of challenges facing member countries due to recent crises, IDB Group has continued to assist member countries. IDB Group increased its overall financing by 5.2 percent and project financing by 17 percent in 2008. The Group plans to increase its development assistance further by 15 percent in 2009. In addition, it also responded to assist them through launching specific initiatives, particularly, Programme to assist its LDMCs facing the adverse consequences of the global financial and economic crisis; Jeddah Declaration; Special Programme for the Development of Africa; and Islamic Solidarity Fund for Development.

The IDB Group launched a Programme in January 2009 to assist its least developed member countries facing the adverse consequences of the global financial and economic crisis. The Programme aims at scaling up commitments and disbursements, supporting economic recovery and capacity development. For the period 2008 to 2010, incremental commitments in lending and guarantee operations is estimated at $\$ 6.6$ billion. IDB Group will expedite disbursements for active or on-going projects and programmes and consider disbursements in advance through establishment of special accounts; approve additional projects in public works where disbursement can be made within a very short period of time; reduce the requirement for counterpart funds to be provided by the government in IDB approved projects; consider additional funding if any co-financier withdraws due to the crisis; reduce immediate repayment burden, revise where necessary the project repayment schedules in the most affected countries.

In responding to the food crisis, which engulfed the whole world and negatively affected most member countries, the IDB Board of Governors, at their $33^{\text {rd }}$ Annual Meeting held on 2-4 June 2008 in Jeddah, adopted the Jeddah Declaration committing $\$ 1.5$ billion over five years. This Initiative is aimed at supporting hard hit member countries to strengthen their food security and revitalise their agriculture sector. Through this initiative, the IDB Group is supporting improvements in agriculture productivity and rural incomes through enhancing access to inputs and services, improving infrastructure and strengthening support institutions in the sector.

Poverty and human development continue to be the main focus of the vast majority of IDB member countries, particularly the LDMCs. The IDB Group launched in May 2007 the Islamic Solidarity Fund for Development (ISFD), which formally began its operations in January 2008. The ISFD is in the form of a $\operatorname{Waqf}$ (Trust), with a principal targeted capital of $\$ 10$ billion. The Fund is aimed at reducing poverty in OIC member countries.

\section{CONCLUSION}

2008 was a challenging year for the IDB Group and its member countries because of unprecedented crises. Each crisis has weakened the ability of IDB member countries to meet the challenge of the subsequent crisis. The crises are a source of concern for the IDB Group because of the magnitude of their impact on the economies of member countries and the lives of poor people. They are adversely affected by rising unemployment and poverty, declining private and public foreign capital flows, and sharp deceleration in global output and trade. Consequently, the internationally agreed MDGs appear to suffer a serious setback as the decade-long gains made by member countries are being eroded. 
In 2009, in SSA region, economic growth is projected to slow down and the current account balances is projected to deteriorate due to reduced demand for their exports, lower prices of their commodities, lower flows of remittances, foreign direct investment, ODA and official grants. In the GCC region, although the sharp decline in oil prices have a dampening effects on their growth and current account surpluses, the member countries in the region are expected to sustain public spending, particularly in infrastructure and to boost domestic demand. However, economic recovery in member countries in the coming years will critically depend upon the deepness of economic recession and their policy actions to revive their economies through effective socioeconomic reforms.

Since instruments of Islamic finance are insulated from 'toxic' financial assets and prohibit speculative activities, it can provide better cure for global financial crisis and avoid pro-longed deep economic recession.

\section{REFERENCES}

Asian Development Bank (2009) Global Financial Turmoil and Emerging Market Economies: Major Contagion and a Shocking Loss of Wealth.

Dubai International Financial Exchange and Honk Kong and Shanghai Banking Corporation (2009) HSBC/ DIFX GCC Conventional Financial Services US Dollar Bond Index.

Gulf One Investment Bank (2008) Islamic Finance: Opportunities and Challenges. Research Bulletin 1:12.

Islamic Development Bank (2008) Sovereign Wealth Funds, Current Information Note No. 101.

Islamic Development Bank (2008) The Challenge of Unemployment in IDB Member Countries: Can They Achieve the Target of Full Employment by 2015?

Islamic Development Bank (2008) Achieving the Targets of IDB $1440 H$ Vision and the Millennium Development Goals: Scorecard for Member Countries.

McKinsey and Co (2007) The World Islamic Banking Competitiveness Report 2007/08: Capturing the Trillion Dollar Opportunity.

Millennium Finance Corporation (2009) Gulf Cooperation Council Year Book.

Saudi Gazette (2008) GCC's Private Wealth Reserves Over \$1.5 Trillion.

The Banker Magazine (2008) Top-500 Islamic Financial Institutions, (Supplement).

World Bank (2008) Migration and Development Brief. 